\title{
On the Design of Teaching Activities to Improve Students' English Listening and Speaking Ability
}

\author{
Liao Jing \\ College of Foreign Languages, Wuhan Business University, Wuhan, Hubei, 430000
}

Keywords: English teaching; listening and speaking ability; activity design

\begin{abstract}
With the development of social diversification, people have relatively more demands for language mastery. In addition to our mother tongue, English is another language that must be mastered. English learning is an important learning stage in the whole academic career of students. As an international language, English requires students to not only have a solid English foundation, but also to have a good command of English skills with excellent practice, which must be cultivated from the aspect of English listening and speaking ability. Therefore, this paper will study teaching activities that can improve students' English listening and speaking ability and explore a variety of classroom programs suitable for cultivating students' English ability, enrich teaching methods, so as to improve the quality of English teaching.
\end{abstract}

\section{Introduction}

With the continuous development of economic society, English has been widely applied in our daily life. For students, to cultivate the comprehensive quality talents, it is very important to study English. In the teaching of English, most students are in fear of it, and don't know how to study it, how to apply it; there is no way to remember it, with repeat. At the same time, teachers fail to pay attention to the cultivation of students' English listening and speaking ability in English teaching, which leads to the phenomenon that students cannot apply and express themselves in English. In the reform of English curriculum, it is proposed to change the tradition of paying too much attention to the basic teaching of students' vocabulary and grammar but focus on the development of students' comprehensive language ability. Therefore, in order to improve students' English ability, we must pay attention to the cultivation of English listening and speaking ability.

\section{Significance of Improving Students' English Listening and Speaking Ability}

For students, English listening and speaking is an important link in English teaching. Influenced by the exam-oriented education in the past, most of our traditional teaching focused on more exams tactics to improve the test ability of students. A lot of word explanations and exercises were arranged for students, and the cultivation of students' practical English application abilities were completely ignored. Although students have certain English reading and writing ability, they seriously lack training in listening and speaking skills, which is quite disadvantageous to student's actual application. [1] Cultivating students' English listening and speaking ability is an effective precondition for their practical application. By listening and speaking, students can effectively conduct dialogue and communication in practical communication, so that students can understand the application and significance of English and fully know the role of English. At the same time, by cultivating students' English listening and speaking ability, students can no longer focus on boring words, but learn English in a flexible way in communication and practice, so as to independently improve their interest in English, stimulate their enthusiasm for English, and better cultivate their English level.

With the constant improvement of new curriculum reform, the listening evaluation has been greatly added in the oriented exam, which is enough to prove that the English education in China attaches importance to training students' practical ability; therefore, to achieve the real goal of English teaching and cultivate practical talents, it is very important to improve students' English 
listening and speaking ability, so that it is necessary to enhance students' English listening and speaking training.

\section{Design Criteria for English Teaching Activities}

Normatively designing teaching activities mainly means that the design of English classroom teaching activities should be reasonable and standard, in strict accordance with the training of students comprehensive ability with a purpose to carry on the design, and testing the activity effects. When choosing a certain activity, teachers should illustrate the specific teaching content to students, making students fully prepare, so as to guarantee the teaching effect; at the same time, teachers should give students timely evaluation after the event, letting students have real gains in the teaching of English activities.

There are several large modules in English teaching. Teachers should choose the teaching activities reasonably according to different teaching contents. When designing English teaching activities, teachers should consider whether they are effective, whether they can achieve teaching objectives, and whether they can adapt to students' actual ability.

Teachers should have flexibility for English listening teaching design, and teach with the diverse teaching methods, for example, teachers can undertake teaching by means of cooperation to lead students to participate in the classroom; in terms of the teaching content, they should make activity design according to the students' learning content and actual level; teachers should teach students in accordance of their aptitude, to stimulate students' interest in English.

\section{Focusing on English Teaching Environment Design}

For the cultivation of students' language ability, it is inseparable from the learning atmosphere. Teachers should create learning environment in English classroom to improve students' learning status, so as to teach language knowledge. First of all, teachers should build a relaxed and happy learning atmosphere for students; secondly, they should make students independently participate in classroom activities to take training, and finally conduct the evaluation and guidance on students.

In English listening teaching, students are prone to be timid and shy, may be fearful to speak, speak badly and pronounce inaccurately. Teachers must use the lively teaching method to establish a pleasant class atmosphere, to let the students feel relaxed, bold to express. Teachers should give students all kindness, smile to all students; for students' errors, teachers should be patient, respect students' self-esteem, and give encouragement and motivation to students' performance [2], for example, "Very good", "You're wonderful”, "good job", so as to promote harmony between teachers and students and enhance students' confidence in English communication.

In English class, teachers should try their best to use English for teaching, providing students with a learning environment for applying English, and arousing students' consciousness, so that students can understand what teachers say and broaden their thinking of English. [3] Teachers can also use modern teaching equipment to design flexible teaching activities and create real communication situations. For example, teachers can use multimedia to play English communication dialogues video and short animated films for students, so that students can improve English in an imperceptible way in the whole English atmosphere. Students should encourage students to learn to listen, help students analyze the key points in pronunciation, intonation and speed of speech, and strengthen students' memory through constant edification, so as to form a certain degree of English language sense and thinking.

\section{Creating the Teaching Activities in Diverse Application Forms}

In English teaching, teachers should make reasonable use of class time, and create a relaxed English classroom atmosphere. At the same time, they should pay attention to diversified teaching methods and cultivate students' English application and expression ability. [4] Teachers should give full prominence to students' dominant position in teaching, and apply the teaching concept and 
innovative methods of new curriculum reform to effectively teach English based on students' English level.

To improve students' listening and speaking skills in the teaching process, teachers will exchange information as much as possible in the classroom communication, with frequent transformation of subjects with students, from the simple and the easy to make students fully challenge and have freshness. Teachers can put forward the dialogues with different difficulty according to the personality characteristics and English language level of students, then to communicate with students randomly, and make students prepare for every question, which not only lets the students think for each question; at the same time, teachers communicate according to personal English level to improve the quality of dialogue and strengthen students' self-confidence in English communication.

Language application cannot be separate from the collective environment and social interaction. To develop students' ability of English listening and speaking, teachers not only improve students' ability and status of applying English expressions at school, but also encourage students to be free and easy to communicate in a certain language environment, so teachers will organize students to practice in team, enhance students' practical experience, improve students' subjectivity in English, which is beneficial to promote the development of students' English communication ability.

[5] Teachers can group students in English teaching, through the cooperation teaching method, and ask students to use English to communicate and discuss. Teachers should also be involved in it and communicate with the team, and give evaluation, and summed up it in a timely manner. Through team cooperation, they learn from each other and complement each other. Teachers can innovate more teaching activities to stimulate students' enthusiasm for English in teaching. For example, for the eight unit of grade seven, "When is your birthday?", teachers can ask each member to introduce themselves, characters and hobbies to each other in a detailed way by extending the title in team. After that, teachers can test the depth of dialogues in a group, so as to train students to learn English better in a relaxed state.

In English teaching, to cultivate students' comprehensive English level, teachers also need to train students' logical expression ability and improve students' English depth, so that students can truly understand the charm of English. Teachers can use the innovative teaching concept to set up picture talk activities, which not only enhances students' interest in learning, but also helps students to better develop thinking. [6] Teachers can design pictures according to the content of each chapter in class. For example, for the junior English "Do you like bananas?”, teachers can choose a variety of animation banana pictures to let students grouped to create stories around banana according to the pictures and give students enough space; the whole story is discussed by students; eventually the group tell it in English, and then teachers give feedback. In this application form, it can improve students' English thinking, and effectively exercise students' English communication independently.

When cultivating students' English listening and speaking ability, teachers can simulate different scenes according to the requirements of teaching content to let students play roles, stimulating students' ability to use English, and cultivating students' ability to organize language. At the same time, teachers can make students play the role they like to conduct situational dialogues through activities. This kind of situational mode not only trains students' expression ability, but also gives them a sense of reality. It also exercises students' ability of English expression speed, pronunciation and intonation, which plays a significant role in improving students' English quality. [7] In this way, students can improve their comprehensive English expression ability in communication. For example, for "My class", teachers can ask students to adapt conversations by title. A: How many people are there in your class? B: Tweny A: Who are they? B: My deskmate. It improves students' communication skills in this way.

\section{Setting English Incentive System}

Creating English speech, setting up incentive mechanism. Teachers can organize an English speaking activity in the teaching each month, or design corresponding English speech in a semester according to the teaching contents; at the same time, the social incentive mechanism encourages 
students to actively participate in it, setting English example, excellent campus English student and grade good English good student, etc., letting students effectively practice speaking, and exercise students to fluently speak English in real life. Through English speaking activities, it cultivates students not to be afraid, better cultivating students’ English comprehensive ability.

\section{Conducting Extra-curricular Activities and Strengthening Language Practice}

In English teaching, teachers should not only innovate English classroom teaching, but also organize extracurricular English activities to strengthen students' English training. Teachers can use the network to find the appropriate English conversation, English plays, English games before class to carry out teaching activities, for example, English knowledge competition, losers taking English word examination, singing an English song and so on. By teaching in the entertainment, it not only increases students' English knowledge, but also stimulates students' interest in learning of English. It also can let the teacher know students in the interaction, help students improve their English, and carry on the teaching from multiple angles, with the implementation of education innovation.

Conclusion: In short, to improve students' English level, it will improve the cultivation of student's English listening and speaking skills, and teachers should innovate teaching activities, design targeted teaching plan according to the characteristics of e students and their English level; teachers should use flexible teaching methods to build an active English classroom atmosphere, so as to arouse students' enthusiasm for English learning, and improve students' learning initiative, making them better master English.

\section{References}

[1] Song Xin. Teaching activity design to improve students' English listening and speaking ability. Journal of Jilin Provincial Institute of Education, 2015,31(10):36-37.

[2] Wang Yanhua. On the cultivation of students' listening and speaking ability in middle school English teaching. Learning Weekly, 2016(08):182.

[3] Chen Qiaoping. Strategies to improve students’ English listening and speaking ability. Xu Shu Wai Xue Xi (English education), 2013(01):134.

[4] Feng Zhenzhen. On strategies to effectively improve students' listening and speaking ability in and after middle school English classes. Campus English, 2017(21):106.

[5] Zhao Jingjing. On the current situation of college English listening and speaking ability and its causes. Journal of Harbin institute of vocational technology, 2011(02):75-76. 